\title{
ДЕЛЕГОВАНІ ДЕРЖАВНІ ПОВНОВАЖЕННЯ \\ У СТРУКТУРІ КОМПЕТЕНЦІЇ ОРГАНІВ \\ МІСЦЕВОГО САМОВРЯДУВАННЯ В УКРАЇНІ \\ ТА ДЕЯКИХ ЄВРОПЕЙСЬКИХ КРАЇНАХ
}

Новак А. О.

\section{ВСТУП}

Делегування повноважень органів виконавчої влади органам місцевого самоврядування вбачається важливим із точки зору не лише оптимізації загальнодержавного механізму публічно-владного управління, але й розширення функціонально-компетенційної сфери діяльності муніципальних органів задля найповнішого задоволення потреб життєзабезпечення населення сіл, селищ та міст, наближення системи адміністративного обслуговування до пересічних громадян. Нині «питома вага» делегованих повноважень у структурі компетенції органів місцевого самоврядування відповідно до Закону України «Про місцеве самоврядування в Україні» становить 48\%. Така значна частка делегованих повноважень закономірно зумовлює науковий інтерес до виявлення специфіки делегованих повноважень щодо інших видів повноважень, визначення їх місця та ролі у структурі компетенції цих органів.

Світова та українська юридична наука традиційно приділяє значну увагу проблемам правового регулювання компетенції місцевого самоврядування та його органів. Зокрема, можна назвати праці таких науковців, як М.О. Баймуратов, О.В. Батанов, I.I. Бодрова, В.І. Борденюк, Г.В. Бублик, В.М. Кампо, А.М. Колодій, M.I. Корнієнко, В.В. Кравченко, А.Р. Крусян, В.С. Куйбіда, П.М. Любченко, О.Ю. Лялюк, О.В. Марцеляк, С.Г. Серьогіна, К.Є. Соляннік, Ю.М. Тодика, В.Л. Федоренко, І.С. Щебетун та інші. Проте комплексні дослідження делегованих повноважень зустрічаються нечасто та не вичерпують усієї проблематики питання.

Реформи децентралізації влади були проведені наприкінці XX на початку XXI століття більшістю сучасних європейських держав. Основними напрямами їх стали розвиток місцевого самоврядування, регіоналізм та демократизація публічного управління. У межах цих реформ національні моделі місцевого самоврядування зазнали змін, пов'язаних зі збільшенням кількості делегованих державою повноважень, посиленням фінансової самостійності, а також спрощенням системи державного контролю за діяльністю органів місцевого 
самоврядування. Раціональний розподіл повноважень і відповідальності між органами виконавчої влади і органами місцевого самоврядування дав змогу забезпечити в зарубіжних країнах найбільш ефективну взаємодію цих структур, створити умови для належного життєзабезпечення та гармонійного розвитку людини, забезпечити комплексний та стабільний територіальний розвиток на основі найповнішого використання потенціалу адміністративно-територіальних одиниць.

Вивчення зарубіжного досвіду дає змогу знайти правильні механізми вирішення проблем, пов'язаних із делегуванням державних повноважень органам місцевого самоврядування в Україні, особливо за умов започаткованої в країні реформи децентралізації влади.

\section{1. Особливості делегованих повноважень органів} виконавчої влади у структурі компетенції органів

\section{місцевого самоврядування і проблеми їх здійснення в Україні}

У загальному колі повноважень органів місцевого самоврядування в Україні законодавчо виокремлено такі їх види: власні, делеговані та виключні повноваження. Проте легальне визначення законодавець надав лише поняттю делегованих повноважень. Визначення ж понять власних та виключних повноважень опрацьовуються на підставі аналізу муніципально-правових норм. Водночас виключні повноваження, якими Закон України «Про місцеве самоврядування в Україні» (далі - Закон № 280/97-ВР) наділив сільські, селищні, міські (ст. 26) та районні, обласні (ст. 43) ради, цілком слушно запропоновано розглядати як різновид власних повноважень ${ }^{1}$.

Власними повноваженнями науковці пропонують визначати повноваження, закріплені нормами муніципального права за суб'єктами місцевого самоврядування, щодо вирішення питань місцевого значення, тобто справ, що безпосередньо стосуються життєдіяльності громади і відповідають iї управлінським та фінансовим можливостям².

Делеговані ж повноваження відповідно до ст. 1 Закону № 280/97-ВР визначаються як повноваження органів виконавчої влади, надані органам місцевого самоврядування законом, а також повноваження органів місцевого самоврядування, які передаються відповідним місцевим

\footnotetext{
1 Любченко П.М. Муніципальне право України : навч. посібник. Харків : ФІНН, 2012. C. 368 .

Про місцеве самоврядування в Україні : Закон України від 21.05.1997 р. № 280/97-ВР. Відомості Верховної Ради Украӥни. 1997. № 24. Ст. 170.

2 Любченко П.М. Муніципальне право України : навч. посібник. Харків : ФІНН, 2012. C. 382 .
} 
державним адміністраціям за рішенням районних, обласних рад. У цьому визначенні законодавець об'єднав два зустрічних механізми делегування повноважень в Україні між підсистемами органів державної влади та органів місцевого самоврядування. У контексті нашого дослідження звернемо увагу на поняття делегованих повноважень органів виконавчої влади як повноважень органів виконавчої влади, наданих органам місцевого самоврядування законом. Таке визначення має доволі стислий характер та не дає змоги розкрити усієї специфіки таких повноважень. Остання найбільш повно може бути простежена на підставі порівняльного аналізу власних і делегованих повноважень.

Проведений нами аналіз дає змогу виокремити спільні та відмінні риси нормативних моделей власних і делегованих повноважень органів місцевого самоврядування. Так, власні і делеговані повноваження характеризуються спільними рисами:

1) вони встановлюються Законом України «Про місцеве самоврядування в Україні».

Безумовно, нині й інші закони України закріплюють повноваження органів місцевого самоврядування, які можна зарахувати як до власних, так і делегованих, але виключно Законом № 280/97-ВР здійснюється систематизація цих видів повноважень ${ }^{4}$.

В умовах вітчизняної політико-правової практики сам спосіб делегування повноважень свідчить про умовність їх поділу на власні та делеговані. На наш погляд, відмінності між власними і делегованими повноваженнями, принаймні організаційно-правового характеру, зумовлені тим, що останні реалізуються в межах загальнодержавного механізму управління;

2) i власні, i делеговані повноваження мають єдині предметні сфери здійснення.

Виокремити єдиний критерій розмежування предметних сфер здійснення власних і делегованих повноважень доволі складно. Це призвело до того, що в одних і тих самих сферах суспільних відносин реалізуються як власні, так і делеговані повноваження, за незначним виключенням. При цьому власні повноваження превалюють у таких сферах, як соціально-економічний і культурний розвиток, планування та облік, галузь бюджету, фінансів і цін, управління комунальною власністю, житлово-комунальне господарство,

\footnotetext{
3 Про місцеве самоврядування в Україні : Закон України від 21.05.1997 р. № 280/97-ВР. Відомості Верховної Ради Украӥни. 1997. № 24. Ст. 170.

4 Там само
} 
побутове, торговельне обслуговування, громадське харчування, транспорт і зв'язок, будівництво. Частка делегованих перевищує частку власних повноважень у сферах регулювання земельних відносин та охорони навколишнього природного середовища, соціального захисту населення. Майже паритетний характер має співвідношення власних і делегованих повноважень у сферах освіти, охорони здоров'я, культури, фізкультури і спорту, зовнішньоекономічної діяльності, забезпечення законності, правопорядку, охорони прав, свобод і законних інтересів громадян;

3) власні і делеговані повноваження реалізуються в межах єдиної організаційної системи місцевого самоврядування.

Єдина організаційна система місцевого самоврядування тієї чи іншої територіальної громади, включаючи як інституційну, так і процесуальну іiі складові частини, застосовуються для виконання як власних, так і делегованих повноважень. Здійснення делегованих повноважень, як правило, покладається на ті самі структури, що реалізують і власні повноваження.

4) і власні, і делеговані повноваження мають рівною мірою обов'язковий характер.

Будучи встановленими законом України, власні і делеговані повноваження є обов'язковими для виконання відповідними органами та посадовими особами. Це означає, що закон про відповідне наділення повноваженнями є загальнообов'язковим для виконання незалежно від бажання, можливості або розсуду цих органів. У зв'язку 3 цим органи місцевого самоврядування зобов'язані реалізовувати приписи Закону № 280/97-ВР. В іншому випадку матиме місце порушення режиму законності.

Обов'язковість до виконання на відповідній території рішень органів місцевого самоврядування, прийнятих у межах як власних, так i делегованих повноважень, гарантується ч. 1 ст. 144 Конституції України

5) власні і делеговані повноваження забезпечуються єдиною системою державного захисту та примусу.

Відповідно до ст. 18 Закону № 280/97-ВР орган місцевого самоврядування може бути позивачем та відповідачем у судах загальної юрисдикції, зокрема, звертатися до суду, якщо це необхідно для реалізації повноважень і забезпечення виконання функцій місцевого

\footnotetext{
5 Конституція України : Конституція, Закон України від 28.06.1996 p. № 254к/96-ВР. Відомості Верховної Ради. 1996. № 30. Ст. 141.
} 
самоврядування ${ }^{6}$. При цьому законодавець не розмежовує судові механізми захисту з питань реалізації власних або делегованих повноважень;

6) власні і делеговані повноваження мають постійний характер.

I власні, і делеговані повноваження можуть бути відкликані лише через внесення змін до закону.

7) обидва види повноважень здійснюються під громадським контролем.

I власні, і делеговані повноваження здійснюються прозоро, що забезпечується активною участю громадськості в здійсненні контролю за наданням населенню соціальних послуг у системі місцевого самоврядування, гласністю в прийнятті рішень муніципальними органами, можливістю точного визначення потреб населення та оперативного реагування на місцеві ініціативи, включенням населення - споживачів послуг до організації їх надання тощо ${ }^{7}$

Ключову роль у розмежуванні власних і делегованих повноважень відіграють їхні відмінні риси, які простежуються за такими критеріями:

1) за характером повноважень.

Власні повноваження - повноваження самоврядні, як на це вказав сам законодавець, тим самим підкресливши органічну приналежність їх місцевому самоврядуванню як самостійній формі публічної влади в Україні. Ця влада у своїй діяльності виходить з інтересів населення відповідної території.

В основі ж делегованих повноважень - завдання загальнодержавного характеру. Як такі, вони грунтуються на інтересах усього народу України та зумовлюються потребами розвитку суспільства і держави. Проте можливість та необхідність адаптування делегованих повноважень до місцевих умов істотно впливає на них. Реалізуючи у процесі виконання делегованих повноважень загальнодержавні інтереси, органи місцевого самоврядування мають найповніше враховувати місцеві інтереси та місцеву специфіку.

Отже, вважаємо, що делеговані повноваження необхідно розглядати як особливий вид повноважень органів місцевого самоврядування, правова природа яких має складний державно-муніципальний

\footnotetext{
6 Про місцеве самоврядування в Україні : Закон України від 21.05.1997 р. № 280/97-ВР. Відомості Верховної Ради Украӥни. 1997. № 24. Ст. 170.

7 Кравченко В.В. Форми участі неурядових структур у розвитку місцевого самоврядування. Актуальні проблеми виконання законів України «Про місиеве самоврядування в Україні» та «Про місиеві державні адміністрачії» / за ред. В.В. Кравченка. Київ : Атіка, 2003. C. 51.
} 
характер, базується на поєднанні державних і місцевих інтересів, що здійснюються під контролем уповноважених державних органів, але з адаптуванням процесу їх реалізації до особливостей місцевого самоврядування окремих територіальних громад;

2) за об'єктом здійснення.

Власні повноваження органів місцевого самоврядування спрямовані на вирішення питань місцевого значення, у той час як делеговані повноваження не пов'язані з вирішенням питань місцевого значення. Принципове знаходження предмета таких повноважень за межами цих питань зумовлене політико-правовою природою розмежування державної влади та місцевого самоврядування як самостійних форм публічної влади. Як зазначає В.I. Васильєв, державні повноваження - повноваження, правові, організаційні, соціально-економічні наслідки реалізації яких пов'язані не тільки з безпосереднім забезпеченням життєдіяльності населення муніципального утворення, як це характерно для муніципальних повноважень, але й населення, відповідно, усієї держави

3) за первинним носієм повноважень.

Територіальна громада традиційно з точки зору муніципально-правової теорії і практики, а також з огляду на законодавчі приписи ч. 1 ст. 6 Закону № 280/97-ВР визнається первинним суб' єктом місцевого самоврядування, основним носієм його функцій і повноважень ${ }^{9}$. Але водночас необхідно зауважити, що це стосується саме власних (самоврядних) функцій і повноважень, які, як зазначає О.В. Батанов, реалізуються в межах певної території, відведеної для цих цілей державою $^{10}$. Делеговані ж повноваження, як одна 3 правових форм втілення державної влади, первинно $є$ похідними від влади усього народу України. Відповідні повноваження, будучи закріпленими як делеговані, дають змогу частково інтегрувати муніципальне управління до загальнодержавного механізму, забезпечуючи реалізацію інтересів усього народу України;

4) за призначенням повноважень.

Власні повноваження випливають із потреб життєзабезпечення територіальних громад та спрямовані на належне та самостійне їхне функціонування в межах, визначених законом. Делеговані ж

\footnotetext{
8 Васильев В.И. Местное самоуправление : учеб. и науч.-практич. пособие. Москва : Юринформцентр, 1999. С. 376.

9 Про місцеве самоврядування в Україні : Закон України від 21.05.1997 р. № 280/97-ВР. Відомості Верховної Ради Украӥни. 1997. № 24. Ст. 170.

10 Батанов О.В. Муніципальна влада в Україні: проблеми теорії та практики : монографія. Київ : Юрид. думка, 2010. С. 314.
} 
повноваження покликані раціоналізувати механізм державного управління на засадах субсидіарності та децентралізації влади.

Прикладом може слугувати Закон України «Про внесення змін до деяких законодавчих актів України щодо розширення повноважень органів місцевого самоврядування та оптимізації надання адміністративних послуг» № 888-VIII від 10.12.2015 р. яким було доповнено Закон № 280/97-ВР статтею 37-1, згідно $з$ якою до відання виконавчих органів сільських, селищних, міських рад зараховане таке делеговане повноваження, як формування та ведення реєстру територіальної громади відповідно до закону ${ }^{11}$. На перший погляд, питання обліку членів територіальної громади повинно мати власний (самоврядний) характер. Але законодавець тим самим фактично поклав на відповідні органи місцевого самоврядування повноваження щодо реєстрації місця проживання фізичних осіб. Така реєстрація відіграє роль юридичного факту в багатьох правовідносинах. Крім того, ведення реєстру територіальної громади є важливим для формування загальнодержавних демографічного та виборчого реєстрів. Отже, реалізація цього повноваження спрямована не тільки на організаційне забезпечення функціонування територіальної громади як первинного суб'єкта місцевого самоврядування, але й на виконання загальнодержавних завдань, забезпечення реалізації правового статусу громадян України;

5) за колом суб'єктів.

На відміну від власних повноважень, якими наділені всі суб'єкти місцевого самоврядування, делеговані повноваження встановлені Законом № 280/97-ВР виключно за виконавчими органами сільських, селищних, міських рад ${ }^{12} .3$ усієї системи муніципальних органів лише виконавчі структури, зазначає К.С. Соляннік, здатні здійснювати такий напрям роботи. Завдяки організаційній структурі, штату працівників, формам і методам роботи останні матимуть реальну можливість реалізації функцій виконавчої влади. Інші утворення муніципального апарату не задовольняють вимог виконавчої діяльності, яка потребує професійності, оперативності, відповідної субординації тощо ${ }^{13}$;

11 Про внесення змін до деяких законодавчих актів України щодо розширення повноважень органів місцевого самоврядування та оптимізації надання адміністративних послуг : Закон України від 10.12.2015 р. №888-VIII. Відомості Верховної Ради України. 2016. № 3. Ст. 30.

12 Про місцеве самоврядування в Україні : Закон України від 21.05.1997 р. № 280/97-ВР. Відомості Верховної Ради України. 1997. № 24. Ст. 170.

13 Проблеми функціонування місцевих рад та їх виконавчих органів : монографія / за ред. Ю.М. Тодики. Харків : Право, 2009. С. 492. 
6) за правовою основою здійснення повноважень.

3 огляду на конституційне (ч. 1 ст. 140) та законодавче (ч. 1 ст. 2 Закону № 280/97-ВР) визначення поняття місцевого самоврядування, діяльність із самостійного вирішення територіальними громадами безпосередньо або через органи та посадових осіб місцевого самоврядування питань місцевого значення, тобто здійснення власних (самоврядних) повноважень обмежується виключно Конституцією і законами України ${ }^{14}$.

Водночас ч. 3 ст. 24 Закону № 280/97-ВР зобов'язує органи місцевого самоврядування та їхніх посадових осіб керуватися у своїй діяльності Конституцією і законами України, актами Президента України, Кабінету Міністрів України, а в Автономній Республіці Крим - також нормативно-правовими актами Верховної Ради і Ради міністрів Автономної Республіки Крим, прийнятими в межах їхньої компетенції ${ }^{15}$. Однак Закон не розмежовує діяльність із реалізації власних або делегованих повноважень. У практичній площині це зумовлює наявність значної кількості підзаконних правових актів, що визначається як негативна риса сучасної правової політики у сфері місцевого самоврядування.

Реалізуючи власні повноваження та керуючись принципом правової самостійності місцевого самоврядування, суб'єкти місцевого самоврядування самостійно і під свою відповідальність приймають рішення нормативного, установчого, правозастосовного та іншого характеру, спрямовані на вирішення питань місцевого значення. При цьому частка муніципальної нормотворчості з власних повноважень $\epsilon$ доволі значною.

Що стосується регулювання делегованих повноважень, муніципальна нормотворчість має звужений характер. Діяльність муніципальних органів із реалізації таких повноважень має організаційно-розпорядчий характер. Предметом регулювання стає організація управління: система та структура уповноважених органів, їх функції, порядок діяльності, процедурно-процесуальні аспекти реалізації повноважень.

Водночас маємо звернути увагу на те, що залишається мало використаним регулятивний потенціал статутів територіальних громад. Роль статутної нормотворчості, на наш погляд, могла б полягати,

\footnotetext{
14 Конституція України : Конституція, Закон України від 28.06.1996 p. № 254к/96-ВР. Відомості Верховної Ради. 1996. № 30. Ст. 141.

Про місцеве самоврядування в Україні : Закон України від 21.05.1997 р. № 280/97-ВР. Відомості Верховної Ради Украӥни. 1997. № 24. Ст. 170.

15 Там само 
зокрема, у визначенні функціональної ролі конкретних органів місцевого самоврядування в організації та здійсненні делегованих повноважень, закріпленні вимоги здійснення делегованих повноважень 3 урахуванням особливостей територіальної громади, встановленні гарантій та форм взаємодії органів місцевого самоврядування 3 територіальною громадою, iї представниками з питань реалізації делегованих повноважень та ін.;

7) за територіальною основою здійснення повноважень.

Власні повноваження, утворюючи зміст функціонування суб'єктів місцевого самоврядування щодо вирішення питань місцевого значення, реалізуються на всіх територіальних рівнях системно-структурної організації муніципальної влади - обласному, районному, локальному (сільському, селищному, міському), сублокальному (тобто на рівні функціонування органів самоорганізації населення). Чітке законодавче окреслення територіальних видів виконавчих органів місцевих рад, за якими Закон України «Про місцеве самоврядування в Україні» визначає коло делегованих повноважень, обмежує територіальну основу здійснення таких повноважень локальним рівнем місцевого самоврядування;

8) за матеріально-фінансовою основою здійснення повноважень.

Відповідно до ч. 3 ст. 16 Закону № 280/97-ВР матеріальною і фінансовою основою місцевого самоврядування є рухоме і нерухоме майно, доходи місцевих бюджетів, інші кошти, земля, природні ресурси, що $\epsilon$ в комунальній власності територіальних громад сіл, селищ, міст, районів у містах, а також об'єкти їхньої спільної власності, що перебувають в управлінні районних і обласних рад ${ }^{16}$.

Ч. 3 ст. 143 Конституції України гарантовано: держава фінансуєздійснення окремих повноважень органів виконавчої влади, наданих органам місцевого самоврядування, у повному обсязі коштом Державного бюджету України або шляхом віднесення до місцевого бюджету у встановленому законом порядку окремих загальнодержавних податків, передає органам місцевого самоврядування відповідні об'єкти державної власності ${ }^{17}$. Норму, що конкретизує джерела матеріальнофінансового забезпечення, містить ч. 1 ст. 67 Закону № 280/97-ВР:

\footnotetext{
16 Конституція України : Конституція, Закон України від 28.06.1996 p. № 254к/96-ВР. Відомості Верховної Ради. 1996. № 30. Ст. 141.

Про місцеве самоврядування в Україні : Закон України від 21.05.1997 р. № 280/97-ВР. Відомості Верховної Ради Украӥни. 1997. № 24. Ст. 170.

17 Конституція України : Конституція, Закон України від 28.06.1996 p. № 254к/96-ВР. Відомості Верховної Ради. 1996. № 30. Ст. 141.
} 
держава фінансово забезпечує здійснення органами місцевого самоврядування наданих законом повноважень органів виконавчої влади у повному обсязі шляхом закріплення за відповідними місцевими бюджетами джерел доходів бюджету, надання трансфертів із державного бюджету, а також передання органам місцевого самоврядування відповідних об'єктів державної власності ${ }^{18}$.

Принципово важливе значення має використане у вищевказаних конституційній та законодавчій нормах формулювання «в повному обсязі», яке передбачає нормативну вимогу повного покриття видатків, пов'язаних із виконанням органами місцевого самоврядування державних делегованих повноважень, за рахунок державних фінансів та об'єктів державної власності;

9) за можливістю делегування повноважень.

Слугуючи меті найбільш раціонального та ефективного вирішення питань місцевого значення, Закон України № 280/97-ВР передбачає широкий спектр можливих напрямів перерозподілу власних (самоврядних) повноважень органів місцевого самоврядування, що виступає важливим засобом забезпечення організаційної самостійності місцевого самоврядування. Зокрема, для прикладу, такі повноваження можуть бути делеговані: районними, обласними радами - відповідним місцевим державним адміністраціям (п. 27 ч. 1 ст. 43, ст. 44 Закону України № 280/97-ВР); сільськими, селищними, міськими, районними в місті (у разі їх створення) радами - органам самоорганізації населення (ч. 1 ст. 14, п. 20 ч. 1 ст. 26 Закону України № 280/97-ВР, ст. 15 Закону України «Про органи самоорганізації населення») тощо. Крім того, може мати місце й передача власних повноважень (наприклад: передача сільськими, селищними, міськими радами повноважень обласним і районним радам (ч. 2 ст. 10 Закону України № 280/97-ВР); передача повноважень виконавчого органу сільської ради, що представляє територіальну громаду, яка налічує до 500 жителів, сільському голові (ч. 3 ст. 11 Закону № 280/97-ВР) тощо) ${ }^{19}$.

На відміну від цього, делеговані повноваження органів виконавчої влади закріплюються Законом України «Про місцеве самоврядування в Україні» за чітко визначеним суб'єктом - виконавчими органами сільських, селищних, міських рад, не допускаючи можливості їх переделегування або передачі іншим суб' сктам. Оскільки це суперечило б

18 Про місцеве самоврядування в Україні : Закон України від 21.05.1997 р. № 280/97-ВР. Відомості Верховної Ради України. 1997. № 24. Ст. 170.

19 Там само 
намірам та завданням делегування. Передбачена ж ч. 3 ст. 52 Закону № 280/97-ВР можливість сільської, селищної, міської ради прийняти рішення про розмежування повноважень між їі виконавчим комітетом, відділами, управліннями, іншими виконавчими органами ради та місцевим головою в межах повноважень, наданих цим Законом виконавчим органам сільських, селищних, міських рад, не порушує загальної вимоги здійснення делегованих повноважень виконавчими органами ${ }^{20}$. Адже здійснюється в межах інституційної системи таких органів i передбачає не переделегування повноважень, а забезпечення спеціалізації окремих суб'єктів у механізмі їх реалізації;

10)за характером державного контролю виконання повноважень.

Відповідно до ст. 20 Закону № 280/97-ВР державний контроль за діяльністю органів і посадових осіб місцевого самоврядування може здійснюватися лише на підставі, в межах повноважень та у спосіб, що передбачені Конституцією та законами України, і не має призводити до втручання органів державної влади чи їх посадових осіб у здійснення органами місцевого самоврядування наданих їм власних повноважень ${ }^{21}$.

Власна компетенція органів місцевого самоврядування - це сфера самостійного владарювання відповідних суб'єктів у межах Конституції і законів України. Тому державний контроль обмежується спостереженням за додержанням правових рамок iї здійснення, маючи характер державного нагляду.

На відміну від цього порядку, Конституція України безпосередньо закріплює підконтрольність органів місцевого самоврядування відповідним органам виконавчої влади 3 питань здійснення ними повноважень органів виконавчої влади (ч. 4 ст. 143) 22. Порядок контролю за здійсненням органами місцевого самоврядування делегованих повноважень органів виконавчої влади затверджений Постановою Кабінету Міністрів України від 09.03.1999 р. № 339. Здійснення його покладене на місцеві державні адміністрації, Раду міністрів Автономної Республіки Крим, а у випадках, передбачених законодавством, - на міністерства, інші центральні органи виконавчої влади, їх територіальні органи ${ }^{23}$.

20 Про місцеве самоврядування в Україні : Закон України від 21.05.1997 р. № 280/97-ВР. Відомості Верховної Ради Украӥни. 1997. № 24. Ст. 170.

21 Там само

22 Конституція України : Конституція, Закон України від 28.06.1996 p. № 254к/96-ВР. Відомості Верховної Ради. 1996. № 30. Ст. 141.

23 Про затвердження Порядку контролю за здійсненням органами місцевого самоврядування делегованих повноважень органів виконавчої влади : Порядок, Постанова Кабінету Міністрів України від 09.03.1999 р. № 339.Офіиійний вісник Украӥни. 1999. № 10. Ст. 390. 
Зміст контрольної діяльності, передбаченої урядовим актом, свідчить про те, що державний контроль за делегованими повноваженнями має форму предметного контролю, що стосується не тільки правомірності, але й доцільності розв'язання тих чи інших завдань ${ }^{24}$. Контроль виконання делегованих повноважень передбачає не тільки спостереження за станом їх виконання, але й коригування допущених порушень.

Нинішній стан правового регулювання і здійснення органами місцевого самоврядування делегованих повноважень органів виконавчої влади свідчить про необхідність усунення,деяких негативних рис, як-от:

1) застарілість системи делегованих повноважень. Кількісні показники системи делегованих повноважень свідчать про те, що, на відміну від передбаченого Законом України «Про місцеве самоврядування в Україні» розподілу власних і делегованих повноважень виконавчих органів сільських, селищних, міських рад, коло останніх істотно розширюється на рівні галузевих законів, що призводить до превалювання їх над числом повноважень самоврядного характеру. Розв'язання цієї проблеми пов' язується з переглядом розподілу власних і делегованих повноважень шляхом муніципалізації частини делегованих повноважень;

2) невизначеність галузевого законодавства щодо природи повноважень органу місцевого самоврядування - чи є воно власним, чи делегованим, за незначним виключенням окремих законів. У правозастосовній діяльності муніципальними службовцями це питання вирішується шляхом співвідношення норми галузевого закону із відповідними нормами Розділу II Закону № 280/97-BP25. Проте такий підхід, на наш погляд, має велику частку суб'єктивізму і часто залежить від компетентності та професіоналізму посадових осіб органів влади. Вважаємо, що розмежовувати власні та делеговані повноваження необхідно за чіткою вказівкою закону. Якщо останній не передбачає їхнього делегованого характеру, такі повноваження необхідно вважати власними;

3) виключно законодавчий спосіб делегування органам місцевого самоврядування окремих повноважень органів виконавчої влади.

24 Любченко П.М. Муніципальне право України: навч. посібник. Харків : ФІНН, 2012. C. 389 .

25 Про місцеве самоврядування в Україні : Закон України від 21.05.1997 р. № 280/97-ВР. Відомості Верховної Ради Украӥни.1997. № 24. Ст. 170. 
Такий порядок найменшою мірою здатен забезпечити врахування органами державної влади місцевих умов здійснення повноважень та оперативного розв'язання тієї чи іншої управлінської проблеми. У зв'язку з цим вкрай необхідним видається запровадження обов'язкового (законодавчого) та добровільного (договірного) видів делегованих повноважень, що дасть змогу лібералізувати наявний спосіб делегування повноважень та підвищити його ефективність. Доцільно також у цьому аспекті впровадити практику укладання адміністративних договорів під час застосування договірного способу делегування органам місцевого самоврядування повноважень органів виконавчої влади;

4) нечіткість визначення у тексті ч.ч. 3, 4 ст. 143 Конституції України ${ }^{26}$ кола органів місцевого самоврядування, яким можуть бути надані повноваження органів виконавчої влади, що викликає питання про можливість такого надання й представницьким органам місцевого самоврядування. Отже, це може ставити останні у підконтрольний органам виконавчої влади стан. Одночасно невизначеним залишається і коло «відповідних органів виконавчої влади», які мають контролювати здійснення органами місцевого самоврядування наданих їм повноважень органів виконавчої влади;

5) покладання виконання делегованих повноважень на органи місцевого самоврядування без їхнього повного матеріально-фінансового забезпечення, внаслідок чого спостерігається скорочення видатків місцевих бюджетів на виконання власних повноважень та інших сфер муніципальної діяльності. Незабезпечення реалізації делегованих повноважень матеріально-фінансовими ресурсами не позбавляє органи місцевого самоврядування обов'язку їх виконання, оскільки в іншому випадку матиме місце порушення законності в їх діяльності. Але переконані, що у цьому питанні права та законні інтереси місцевого самоврядування мають бути забезпечені гарантіями правового, в тому числі й судового, захисту. У процесі матеріально-фінансового забезпечення реалізації делегованих повноважень має бути забезпечена також його співмірність делегованим повноваженням;

6) невизначеність виду і меж відповідальності органів місцевого самоврядування за невиконання або неналежне виконання делегованих повноважень. На нашу думку, необхідно надати головам місцевих державних адміністрацій повноваження щодо зупинення незаконних

26 Конституція України : Конституція, Закон України від 28.06.1996 р. № 254к/96-ВР. Відомості Верховної Ради. 1996. № 30. Ст. 141. 
актів органів місцевого самоврядування, прийнятих із питань виконання делегованих повноважень органів виконавчої влади.

Означене зумовлює потребу істотної модернізації конституційного регулювання як інституту делегованих повноважень, так і місцевого самоврядування загалом в Україні. Вирішення більшості окреслених проблем ми пов'язуємо з необхідністю прийняття окремого, базового закону «Про делегування органам місцевого самоврядування окремих повноважень органів виконавчої влади», норми якого мають не лише систематизувати делеговані повноваження, але й визначати умови делегування та реалізації таких повноважень.

\section{2. Особливості здійснення державних делегованих повноважень в деяких свропейських країнах: досвід для України}

Формування сучасної конституційно-правової моделі інституту місцевого самоврядування в Україні супроводжується значною кількістю проблем, пов'язаних із делегуванням державних повноважень органам місцевого самоврядування. У зв'язку з цим необхідно активно виявляти і поширювати кращі досягнення зарубіжної теорії та практики. При цьому важливо враховувати, що кожна країна має свої особливості й механічне запозичення зарубіжного досвіду не завжди призводить до позитивних результатів на практиці.

У країнах Європи інститут делегування державних повноважень органам місцевого самоврядування відомий ще 3 часів римського права. Приміром, ще у 1790 р. в доповіді щодо законопроекту про реформу місцевого самоврядування, представленій у Національних зборах Франції, виокремлювалися справи, за своєю природою властиві муніципальному управлінню, і справи державні, які передаються органам місцевого самоврядування ${ }^{27}$.

Крім національного досвіду, на сучасному етапі положення міжнародного права сприяють виробленню у зарубіжних країнах універсальних стандартів у сфері спрямування державою повноважень на місцевий рівень. Зокрема, йдеться про положення Європейської хартії місцевого самоврядування, в ст. 4 якої закріплено право центральних або регіональних органів влади делегувати свої повноваження органам місцевого самоврядування, оскільки останні мають найтісніший контакт із громадянами. Органи місцевого самоврядування у міру

27 Пивоваров К.А. Делегирование государственных полномочий местным органам власти: зарубежный опыт. Сибирский Юридический Вестник. 2002. № 1. URL: http://www.lawinstitut.ru/ru/science/vestnik/20021/ pivovarov.html. 
можливості мають право пристосовувати делеговану діяльність до місцевих умов ${ }^{28}$. Як зазначають українські вчені, виходячи із положень Європейської хартії місцевого самоврядування, основою делегованих повноважень є загальновизнаний принцип субсидіарності. Згідно 3 цим принципом у процесі делегування місцеві органи влади виступають як інструмент якісного вирішення публічних справ ${ }^{29}$.

У політико-правовій практиці європейських країн застосовуються різні способи взаємодії органів державної влади та місцевого самоврядування, специфіка яких зумовлена тією або іншою концепцією місцевого самоврядування в країні (державницькою, громадівською або теорією муніципального дуалізму).

Розглядаючи особливості конституційно-правового регулювання делегованих повноважень органів місцевого самоврядування в європейських країнах, в яких втілено різні концепції місцевого самоврядування, варто підтримати думку П.М. Любченка. Основні теорії місцевого самоврядування повною мірою не задовольняють новітніх потреб суспільного розвитку ${ }^{30}$. А тому навіть у межах однієї концепції місцевого самоврядування можуть бути певні відмінності в державах. 3 огляду на це, в межах одного дослідження неможливо охопити досвід усіх європейських країн, а тому розглянемо окремі проблемні питання теорії та практики делегування повноважень, які, на нашу думку, є найбільш вагомими для проведення реформ децентралізації влади в Україні.

Державницька теорія вбачає у місцевому самоврядуванні частину держави - одну з форм організації державного управління. В її умовах муніципальні органи найбільшою мірою контролюються центральною владою. Відтак, у країнах, що тяжіють до державницької концепції місцевого самоврядування, на муніципалітети держава поклала виконання своїх власних функцій. До 90-х років ХХ ст. саме така взаємодія між державою і територіальними колективами мала місце в багатьох країнах Європи. Однак нині ця модель місцевого управління в Свропі майже відсутня і характерна для конституційного законодавства пострадянських республік. Останні намагаються імплементувати

28 Європейська хартія місцевого самоврядування : Хартія, міжнародний документ від 15.10.1985 p. URL: http://zakon2.rada.gov.ua/laws/show/ 994036.

29 Онупрієнко А.М. Делегування державних повноважень місцевим органам влади: світовий досвід. Проблеми законності. 2009. № 102. С. 30.

30 Любченко П.М. Місцеве самоврядування в системі інститутів громадського суспільства: конституційно-правовий аспект : автореф. дис. ... д-ра юрид. наук : 12.00.02 / Нац. юрид. акад. України ім. Я. Мудрого. Харків, 2008. С. 15. 
демократичні стандарти місцевого самоврядування, але радянській досвід управління впливає на «бронювання» за державою патронажної функції щодо функціонування муніципалітетів. Така державна опіка втілюється, зокрема, в практику делегування органам місцевого самоврядування державних повноважень і ресурсів для виконання на місцевому рівні гарантованих державою зобов'язань та послуг ${ }^{31}($ конституції: Республіки Вірменія (ст. 105), Республіки Казахстан (ст. 89), Республіки Узбекистан (ст. 101), Киргизької Республіки (ст. 113) та ін.).

У тих країнах, де модель місцевого управління сформувалася відповідно до концепції муніципального дуалізму, держава майже завжди покладає на місцеве самоврядування виконання окремих своїх функцій і повноважень, розглядаючи в такому контексті муніципальні органи як автономні утворення, які виконують роль агентів держави з чітко визначеного кола завдань. Найчастіше в таких країнах делеговані державні повноваження органів місцевого самоврядування поділяються на обов'язкові та добровільні.

Нині концепція муніципального дуалізму місцевого самоврядування отримала поширення в багатьох європейських країнах. Доцільно розглянути особливість конституційно-правового регулювання делегованих державних повноважень органів місцевого самоврядування на прикладі Іспанського Королівства (далі - Іспанія). Інститут делегованих державних повноважень встановлено в Конституції Іспанії (ст. ст. 150,153$)$, він являє собою право держави делегувати свої повноваження автономним співтовариствам, передавати відповідні фінансові кошти, а також здійснювати контроль за їх виконанням ${ }^{32}$. Механізм реалізації делегованих повноважень врегульовано в Органічному законі «Про місцеве самоврядування» (1985 р. $)^{33}$.

Так, у ст. 27 цього Закону вказано на можливість застосування двох рівнів делегування муніципалітетам повноважень - від держави та від автономних співтовариств (областей), умовно кажучи «субделегація». Метою делегування визнається підвищення ефективності державного управління, усунення дублювання адміністративних функцій

31 Popa V., Munteanu I. Local Government Reforms in the Former Soviet Union: Between Hope and Change. Local governments in Eastern Europe, in the caucasus and in Central Asia. URL: http:/unpan1.un.org/intradoc/groups/public/ documents/APCITY/UNPAN008028.pdf.

32 La Constitución española: Constitución de 29.12.1978. «BOE». 1978. núm. 311, 112 págs. URL: http://www.congreso.es/consti/constitucion/indice/titulos/articulos.jsp?ini= $143 \&$ fin $=158 \&$ tipo $=2$.

33 Reguladora de las Bases del Régimen Local, Ley 7/1985, de 2 de abril,. «BOE». 1985. № 80. 20 págs. URL: http://noticias.juridicas.com/ base_datos/Admin/17-1985.t1.html. 
і підтримка бюджетної стабільності та фінансової стійкості. Законом встановлена вимога щодо терміну делегування - воно має здійснюватися на строк, не менше 5 років, а також чітко визначений, перелік функцій і повноважень, які підлягають делегуванню: моніторинг та контроль за забрудненням навколишнього середовища, збереження та технічне обслуговування медичних установ, управління дошкільної освітою і туризмом, реєстрація об'єднань, підприємств та організацій тощо. Здійснювані державою контрольні заходи за станом виконання делегованих повноважень полягають у виданні загальних технічних інструкцій, отриманні від муніципалітету в будь-який час інформації про хід реалізації делегованих повноважень, наданні рекомендацій щодо усунення недоліків, оскарженні актів муніципалітету, відкликанні делегованих повноважень та заміні їх виконавця ${ }^{34}$.

Водночас делегування державних повноважень можливе лише за умови згоди і зацікавленості муніципальної ради, яка, у разі порушення державою фінансових зобов'язань та неможливості ефективно здійснювати власні повноваження, може прийняти рішення про припинення виконання делегованих державних повноважень.

Аналізуючи практику здійснення муніципалітетами функції державних агентів, дослідники зазначають про відсутність одноманітності правових механізмів реалізації делегованих повноважень в Іспанії, оскільки в компетенцію регіональної влади входить адаптація національного базового законодавства відповідно до місцевих умов як у цій сфері, так i в різних галузях (екологічна політика, землекористування, лісне господарство, освіта та охорона здоров'я та ін.). Разом із тим у національних i міжнародних дослідженнях констатується наявність загальних проблем та схожих варіантів їх вирішення в різних регіонах держави ${ }^{35}$.

Серед найбільш поширених проблем делегування державних повноважень в Іспанії виокремлюються такі: 1) виконання муніципалітетами повноважень, які безпосередньо за ними не закріплені, але випливають зі змісту ст. 2 Органічного закону «Про місцеве самоврядування». Ця норма встановлює так звані «нестандартні повноваження» муніципалітетів - право муніципалітетів втручатися в будь-які соціально-економічні сектори з метою задоволення нових потреб своїх

34 Reguladora de las Bases del Régimen Local, Ley 7/1985, de 2 de abril,. «BOE». 1985. № 80. 20 págs. URL: http://noticias.juridicas.com/ base_datos/Admin/17-1985.t1.html.

35 Local and regional democracy in Spain: reccomendation 336 (2013) CG(24)6FINAL / rapporteurs: Marc Cools, Leen Verbeek. Strasbourg, 19-21 March 2013. URL: https:/wcd.coe.int/ ViewDoc.jsp? $\mathrm{p}=\& \mathrm{id}=2041471 \&$ Site $=\&$ direct $=$ true.

Managing across levels of government Spain. OECD Journal on Budgeting. 1997. P. 388. 
громадян або виконувати де-факто делеговані державні повноваження на спеціальній основі, яка передбачає одноразову передачу фінансових ресурсів, не підтверджених надалі; 2) брак фінансування делегованих повноважень; 3) адміністративний контроль за здійсненням таких повноважень достатньо часто перетворюється на нагляд за доцільністю діяльності муніципалітетів, що суперечить ст. 8 Свропейської хартії місцевого самоврядування ${ }^{36}$.

Нині вироблені шляхи вирішення означених вище проблем: 1. Держава делегує функції і повноваження тільки тим муніципалітетам, які мають значний фінансовий, кадровий та управлінський потенціал. 2. Впроваджується політика зменшення «нестандартних повноважень» муніципалітетів, суть якої полягає в праві муніципалітетів їх здійснювати лише за двох умов: а) коли власні повноваження достатньою мірою гарантуються; б) коли реалізація «нестандартних повноважень» не порушує бюджетну стабільність і фінансову стійкість. 3. У багатьох сферах, управління якими делегується на муніципальний рівень, державні завдання вирішуються за допомогою угод, щодо співпраці або спільного фінансування певних заходів, яких щорічно підписується більше 300. 4. Втілюється принцип збалансованості ступеню адміністративного контролю за діяльністю муніципальних органів відповідно до важливості інтересів, які охороняються державою.

Оригінальний підхід до визначення державних делегованих повноважень органів місцевого самоврядування містить конституційне законодавство Республіки Польща (далі - Польща). Закон «Про запровадження базового трирівневого територіального поділу держави» встановив різний статус органів самоврядування воєводств, повітів і гмін, що позначилось, на наш погляд, і на специфіці здійснення делегованих державних повноважень органами місцевого самоврядування.

Відповідно до ч. 2 ст. 166 Конституції Республіки Польща, якщо це виходить з обгрунтованих потреб держави, закон може доручити одиницям територіального самоврядування виконання інших публічних завдань. Закон визначає порядок передачі і спосіб виконання доручених завдань ${ }^{37}$. У польській правовій доктрині прийнято поділяти повноваження органів місцевого самоврядування на власні та делеговані. Делеговані (доручені) завдання - це завдання місцевого самоврядування, призначені державою, що виникають: 1) на підставі

\footnotetext{
36 Європейська хартія місцевого самоврядування : Хартія, міжнародний документ від 15.10.1985 p. URL: http://zakon2.rada.gov.ua/laws/show/994_036

37 Konstytucja Rzeczypospolitej Polskiej: z dnia 2 kwietnia 1997 r. Dz.U., 1997. NR 78. poz. 483. URL: http://www.sejm.gov.pl/prawo/konst/ polski/kon1.htm.
} 
законів (обов'язкові); 2) на основі угод (додаткові), що передаються за взаємною згодою; 3) у результаті передачі повноважень муніципалітетів одного рівня іншому, зокрема, від повітів до гмін. Причому вчені виокремлюють три види обов'язкових делегованих (доручених) завдань: гмін, повітів, воєводств ${ }^{38}$.

Водночас аналіз законів Республіки Польща «Про самоврядування гмін $»^{39}$, «Про самоврядування повітів» ${ }^{40} \mathrm{i}$ «Про самоврядування воєводств» ${ }^{41}$ свідчить про те, що на трьох рівнях територіального управління впроваджено різні варіанти делегування державою своїх завдань. Якщо органам самоврядування воєводств держава надала компетенцію з правом прийняття рішень щодо визначення стратегії розвитку регіону в рамках проведення адміністративної децентралізації, то за повітами закріплено право укладати з урядом договори про виконання державних завдань 3 питань державного управління та укладати договори з гмінами про доручення на проведення публічних завдань. Тільки Закон «Про самоврядування гмін» містить чіткий поділ повноважень гмін на власні та делеговані - обов'язкові та додаткові.

Розглядаючи фінансову основу виконання доручених завдань, варто зазначити раціональний підхід польських правників до створення запобіжних заходів виникнення проблем фінансування делегованих повноважень. На законодавчому рівні гарантовано: 1) отримання муніципалітетом фінансування в обсязі, необхідному для виконання державних завдань; 2) нарахування відсотків за ставкою, встановленою для податкової заборгованості в разі невиконання термінів державного фінансування; 3) розгляд фінансових спорів у суді; 4) частиною власних доходів гмін $є 5 \%$ від доходів, отриманих у зв'язку із виконанням делегованих державних завдань.

Надавши міцні фінансові гарантії органам місцевого самоврядування, держава залишила за собою право не лише наглядати за законністю здійснення доручених завдань, а й контролювати доцільність, надійність і економічність дій муніципалітетів. Зокрема, воєвода може призупинити виконання доручених державних завдань, вказати на

38 Sauer A. The System of the Local Self-Governments in Poland. Research paper. 2013. № 6. 25 p. URL: https://www.amo.cz/wp-content/.../amocz-RP-2013-6.pdf .

39 O samorządzie gminnym: ustawa z dnia 8 marca 1990 r Dz.U. 1990. Nr 16. poz. 95. URL: http://isap.sejm.gov.pl/DetailsServlet?id=WDU19900160095.

40 O samorządzie powiatowym: ustawa z dnia 5 czerwca 1998 r. Dz.U. 1998. Nr 91. poz. 578. URL: http://isap.sejm.gov.pl/ DetailsServlet?id=WDU19980910578.

41 O samorządzie województwa: ustawa z dnia 5 czerwca 1998 r. Dz.U. 1998. Nr 91. poz. 576. URL: http://isap.sejm.gov.pl/ DetailsServlet?id=WDU19980910576. 
виявлені недоліки і встановити терміни їх усунення, скасувати рішення муніципалітету, передати доручені завдання іншому муніципалітету, повідомивши про це компетентного міністра. Крім того, Регіональна палата аудиту здійснює фінансовий контроль та має право анулювати фінансові рішення органів місцевого самоврядування ${ }^{42}$.

Інша модель делегування державних повноважень на регіональний і місцевий рівень була обрана у Французькій Республіці (далі ФР) наприкінці XX століття. Аналіз чинного конституційного законодавства ФР свідчить про застосування цією країною такої концепції передачі компетенції Держави на локальний рівень, яка включає право органів територіальних колективів приймати остаточні рішення і самостійно розпоряджатися фінансами. Такий підхід максимально втілює справжній зміст принципу субсидіарності, закладений в Свропейській хартії місцевого самоврядування. Тому у ст. 72-2 Конституції ФР закріплено трансферт компетенції між Державою і територіальними колективами, який супроводжується наданням коштів, еквівалентних тим, які необхідні для здійснення цісї компетенції. У разі розширення переданої компетенції збільшуються й обсяг фінансових ресурсів ${ }^{43}$.

Вважаємо, що законодавець невипадково обрав термін «трансферт» («переношу», «переміщую»), а не «делегування», адже він як найточніше передає сутність процесу децентралізації публічного управління у ФР.

Вищевказані конституційні положення про трансферт компетенції між Державою і територіальними колективами відображено в Законі «Про розподіл компетенції між комунами, департаментами, регіонами і Державою». Крім того, підтвердженням децентралізації виступає положення Закону про заборону трансферту лише частини функцій Держави до департаментів і регіонів. У департаменті та регіоні для виконання кожної послуги в певній сфері укладається договір між представником держави та головами генеральної і регіональної рад, який затверджується наказом відповідального міністра (ст. 8). У ст. 9 Закону також передбачена можливість трансферту державних послуг комунам, але за умови їх зацікавленості та спроможності ${ }^{44}$.

42 Sauer A. The System of the Local Self-Governments in Poland. Research paper. 2013. № 6. 25 p. URL: https://www.amo.cz/wp-content/.../amocz-RP-2013-6.pdf .

43 Constitution de la République française: constitution du 4 octobre 1958 (Version mise à jour en janvier 2015). URL: http://www.assemblee-nationale.fr/ connaissance/constitution.asp\#titre_12.

44 À la répartition de compétences entre les communes, les départements, les régions et l'Etat *loi Defferre*: Loi du 7 janvier 1983 relative n 83-8 (version consolidée au 08 septembre 2017). URL: https://www.legifrance.gouv.fr/ affichTexte.do?cidTexte=JORFTEXT000000320197. 
У французьких і міжнародних дослідженнях результати трансферту державних повноважень територіальним колективам у ФР оцінюються загалом позитивно. Адже, по-перше, означена державна політика дала змогу реорганізувати та оптимізувати систему органів управління в територіальних колективах. Зокрема, власні відомства Держави були скорочені, а замість них на рівні департаментів і регіонів 3'явилися децентралізовані офіси, які забезпечують співробітництво в соціально-економічному секторі, що раніше належав Державі ${ }^{45}$. По-друге, трансферт державної компетенції сприяв розвитку демократії на місцях, встановленню децентралізованої системи фінансування та зміцнив міжкомунальну співпрацю46. По-третє, надання державних повноважень відповідним колективам у таких сферах, як міське, житлове і регіональне планування, соціальне забезпечення, транспорт тощо супроводжується державними грантами. По-четверте, трансферт державної компетенції збільшив відповідальність мерів муніципалітетів, які часто неефективно витрачали комунальні фінанси ${ }^{47}$.

Наприклад, до 1982 р. історично французька система освіти була доволі централізованою. Із набуттям чинності Закону «Про розподіл компетенції між комунами, департаментами, регіонами і Державою» Держава і територіальні колективи поділили відповідальність у цій сфері. Так, Держава виступає гарантом належного функціонування державної служби та послідовності освіти, а органи влади територіальних колективів відповідають за будівництво, реконструкцію, капітальний ремонт та експлуатацію коледжів, середніх шкіл, спеціальних шкіл, морських і сільськогосподарських навчальних закладів та ін. Кожен департамент і регіон розробляє проектну інвестиційну програму, фіксуючи розташування і потужність громади та кількість учнів, але ухвалює програму префект за пропозицією голови генеральної або регіональної ради після консультацій з освітянською спільнотою ${ }^{48}$.

\footnotetext{
45 Local authority Competence in Europe. Study of the European Committee on Local and Regional Democracy / Prepared with the colaboration of Gerard Marcou, Prof. at Paris I Pantheon-Sorbonne University, Head of the Grale. European Practice Reports. Council of Europe, 08 september 2007. URL: https://wcd.coe.int/ViewDoc.jsp?p=\&id=2041471\&Site=\&direct=true.

46 Les grandes étapes de la décentralisation en France / Line Arsenault. Ministère des Affaires municipales et des Régions. le 21 février 2005. URL: http://www.mamrot.gouv.qc.ca/pub/observatoire_municipal/veille/decentralisation_france.pdf.

47 Actes I et II de la décentralisation : évolution des compétences des collectivités territoriales, la situation en 2008. La France: des territoires en mutation. 2009. URL: http://geoconfluences. ens-lyon.fr/doc/territ/FranceMut/ FranceMutDoc3.htm.

48 Décentralisation et enseignement: dossiers documentaries / Ministère de l'éducation. URL: http://media.education.gouv.fr/file/40/4/1404.pdf.
} 
У країнах, що втілили в політико-правову практику ідеї «громадівської» теорії місцевого самоврядування, місцеві колективи історично отримували високий ступінь автономії від держави у сфері вирішення місцевих справ. Сфери компетенції державної і муніципальної влади, як правило, жорстко розмежовані й чітко окреслені. Нині значне число тих повноважень, які у минулому належали до компетенції органів державної влади й були делеговані місцевому самоврядуванню, згодом перетворилися на власні повноваження та стали невід'ємною складовою частиною муніципальної компетенції 49 .

Така система $є$ типовою для більшості країн англосаксонської правової сім’і, а також зустрічається в деяких країнах континентальної (романо-германської) правової сім’ї. Наприклад, на відміну від багатьох європейських країн, у Португальській Республіці (далі Португалія) чинне законодавство встановлює точний розподіл повноважень між органами публічної влади, тому держава не делегує свої повноваження муніципалітетам. Державні повноваження на регіональному і локальному рівнях, як правило, здійснюються через деконцентровану систему державних установ, розташованих в адміністративних регіонах. Проте муніципалітети можуть брати участь у реалізації національних або регіональних програм розвитку певної території ${ }^{50}$.

Необхідно зазначити, що, починаючи 3 кінця XX століття, у Португалії активно проводяться реформи щодо децентралізації публічного управління, які передбачають можливість надання повноважень держави органам влади самоврядних одиниць. Так, ст. 111 Конституції Португалії закріплює заборону для органів державної влади, автономної області або місцевої влади здійснювати делегування своїх повноважень іншим органам, окрім випадків і в межах, безпосередньо передбачених Конституцією i законом. Водночас встановлено змогу держави на основі закону передавати форми технічної підтримки та людських ресурсів до місцевих органів влади, не зашкоджуючи їх автономії (ст. 243). Незважаючи на чітко визначений розподіл компетенції між державою та органами влади самоврядних одиниць (приходів, муніципій та адміністративних регіонів), принцип адміністративної децентралізації створює фундамент для

49 Serohina S., Bodrova I., Novak A. Delegation of State Powers to Local Self-Government Bodies: Foreign Experience and Ukrainian Realities. Baltic Journal of European Studies. Tallinn University of Technology, 2019. Vol. 9, No. 3 (28). P. 270.

50 Assigning competences and functions to local self-government in four EU member states: a comparative review / prepared by Prof. Salvador Parrado. Madrid: SIGMA, 2005. URL: http://www.sigmaweb.org/publications/ 40987105.pdf. 
перерозподілу компетенції (ст. 237). Гарантування державою місцевим органам влади автономії не перешкоджає Кабінету Міністрів призначати представника Уряду до складу джунти адміністративного регіону (ст. 262). Представник Уряду здійснює адміністративний нагляд (опіку), що полягає в перевірці дотримання законів місцевими органами влади. Проте застосування обмежувальних заходів у рамках адміністративної опіки можливе за умови проведення консультацій із місцевими органами влади (ст. 242) . $^{51}$

Зазначені конституційні положення отримали розвиток у Законі № 159/99, який встановлює рамки трансферту (передачі) завдань і компетенції, необхідних для місцевих органів влади, визначає межі державного втручання у діяльність місцевої адміністрації та закріплює реалізацію принципів адміністративної децентралізації та автономії місцевого самоврядування ${ }^{52}$. Відповідно до ст. 2 цього Закону, децентралізація влади здійснюється на основі принципу субсидіарності за рахунок трансферту (передачі) завдань і компетенції місцевим органам влади $з$ метою забезпечення узгодженості національної і міжрегіональної солідарності, підвищення ефективності i раціональності державного управління та забезпечення прав громадян. У процесі децентралізації центральна і місцева адміністрації мають координувати взаємини за допомогою таких форм партнерства, як консультування, планування, управління, інвестування, спостереження, ліцензування, проектування, фінансування тощо. Як і в інших країнах, у Португалії трансферт завдань і компетенції можливий лише потужним громадам і має супроводжуватися людськими та фінансовими ресурсами й активами, необхідними для їх виконання. На наш погляд, викликає інтерес ст. 5 цього Закону, в якій визначено способи трансферту повноважень залежно від рівня значущості завдань і компетенції: а) передача повноважень, які входять до компетенції місцевих органів влади, здійснюється на основі правил, прийнятих цими органами (передача від муніципій до приходів); б) передача повноважень, передбачених в регіональних програмах, втілюється після консультацій із координаційними комісіями адміністративних регіонів (передача від адміністративних регіонів до муніципій або приходів; в) передача повноважень у рамках реалізації національних програм

51 Constituição da República Portuguesa: Sétima Revisão Constitucional 2005. Diário da República. n. ${ }^{\circ} 155$ - I Série - A, de 12 de agosto de 2005. URL: https://www.parlamento.pt/ ArquivoDocumentacao/Documents/CRPVIIrevisao.pdf.

52 Transferência de atribuições e competências para as autarquias locais: lei de 14 de Setembro n. ${ }^{\circ}$ 159/99. URL: http://www.idesporto.pt/ficheiros/file/Lei_159_1999.pdf. 
здійснюється на основі пріоритетів, встановлених Парламентом за пропозицією Уряду ${ }^{53}$.

У дослідженнях процесів децентралізації публічного управління, які тривають у Португалії, виділяють основні проблеми, пов'язані 3 наданням муніципальним органам державних функцій і повноважень, та шляхи їх подолання:

1) неготовність муніципалітетів прийняти державні завдання і компетенцію через недостатність територіальних, демографічних, фінансових і управлінських масштабів. Ця проблема вирішується в кількох напрямах: а) формування міжмуніципальних утворень (великих міських агломерацій, міжмуніципальних співтовариств, асоціацій приходів і районів спеціального призначення), які здатні реалізувати більшість публічних послуг, забезпечити взаємодію між муніципалітетами і урядовими відомствами та досягти цілей, які становлять спільний інтерес для населення цих міжмуніципальних утворень ${ }^{54}$; б) збільшення державних грантів у таких сферах, як освіта, охорона здоров'я, соціальна інтеграція, культура та ін. ${ }^{55}$; в) технічна підтримка держави структурних реформ органів влади самоврядних одиниць, мета яких - виконання наданих державних завдань ${ }^{56}$;

2) розширення компетенції самоврядних органів зумовило необхідність забезпечення збалансованого розвитку і фінансового вирівнювання різних регіонів країни. Зважаючи на це, Асамблея Республіки ухвалила Закон № 2/2007, який фактично легалізував втручання держави у формування і розподіл місцевих фінансів. Передача державою Загальному муніципальному фонду права здійснювати надання державних фінансів, спрямованих на забезпечення муніципалітетам умов для виконання своїх завдань (ст. 22) ${ }^{57}$. У цьому зв’язку погоджуємося з думкою експертів, що цей Закон створює нову для Португалії модель

53 Transferência de atribuições e competências para as autarquias locais: lei de 14 de Setembro n. ${ }^{\circ}$ 159/99. URL: http://www.idesporto.pt/ficheiros/file/Lei_159_1999.pdf.

54 Regime jurídico das autarquias locais: Lei de 12 de Setembro n. ${ }^{0}$ 75/2013. URL: http://www.pgdlisboa.pt/leis/ lei_mostra_articulado.php?nid=1990\&tabela=leis.

55 Descentralização de competências: anteprojeto de Decreto-Lei. Dossier Municipalização. 2014. URL: http://www.fenprof.pt/Download/FENPROF/SM_Doc/Mid_115/Doc_9133/Anexos/ Anteprojeto_de_Decreto_Lei_-_descentralizacao_de_competencias1.pdf.

56 Programa de Reestruturação da Administração Central do Estado: Relatório Final / Comissão Técnica do Prace. Descentralização. 2006. Anexo 4. URL: http://repositorio.ul.pt/ bitstream/10451/6291/34/ulsd062670_td_anexo_3_PRACE_5.pdf.

57 Lei das Finanças Locais: Lei n. ${ }^{\circ}$ 2/2007. Diário da República, 15 de Janeiro de 2007. 1.a série. N.o 10. URL: http://www.cm-cascais.pt/sites/default/files/anexos/gerais/new/lei_das_financas_locais.pdf. 
взаємин держави і місцевих інституцій, яка передбачає делеговані державні повноваження ${ }^{58}$.

Дослідження конституційно-правового регулювання механізму здійснення муніципальними органами державних делегованих повноважень у деяких європейських країнах свідчить про можливість запозичення окремих заходів організаційно-правового та матеріальнофінансового характеру для України: запровадження обов'язкового і добровільного способу делегування повноважень; проведення консультацій $з$ асоціаціями органів місцевого самоврядування під час вирішення питань обов'язкового делегування повноважень; отримання згоди представницького органу місцевого самоврядування відповідної громади на делегування повноважень при застосуванні його договірного порядку; надання муніципальним органам додаткових правових і матеріально-фінансових гарантій забезпечення їх прав і законних інтересів у процесі здійснення делегованих повноважень; встановлення юридичної відповідальності муніципальних органів за невиконання або неналежне виконання делегованих повноважень.

\section{ВИСНОВКИ}

Делеговані повноваження посідають значне місце у структурі компетенції органів місцевого самоврядування з точки зору як кількісних показників, так і змістовного розширення функціонально-компетенційної сфери діяльності муніципальних органів задля найповнішого задоволення потреб життєзабезпечення населення сіл, селищ та міст, наближення системи адміністративного обслуговування до пересічних громадян.

Порівняльний аналіз нормативних моделей власних і делегованих повноважень органів місцевого самоврядування дав змогу встановити специфіку делегованих повноважень. Зокрема, особливими рисами таких повноважень $є:$ 1) складний державно-муніципальний характер, що базується на поєднанні державних і місцевих інтересів; 2) непов’язаність із вирішенням питань місцевого значення; 3) похідність як однієї з правових форм втілення державної влади від влади усього народу України; 4) призначення раціоналізувати механізм державного управління на засадах субсидіарності та децентралізації влади; 5) обмеження суб'єктного складу виконавчими органами сільських,

\footnotetext{
58 Local authority Competence in Europe. Study of the European Committee on Local and Regional Democracy / Prepared with the colaboration of Gerard Marcou, Prof. at Paris I Pantheon-Sorbonne University, Head of the Grale. European Practice Reports. Council of Europe, 08 september 2007. URL: https://wcd.coe.int/ViewDoc.jsp?p=\&id=2041471\&Site=\&direct=true.
} 
селищних, міських рад; 6) звуженість муніципального рівня правового регулювання відносин, пов'язаних з організацією та здійсненням цих повноважень; 7) матеріально-фінансове забезпечення державними фінансами та об'єктами державної власності; 8) недопущення переделегування або передачі іншим суб'єктам; 10) реалізація під контролем уповноважених державних органів.

На підставі проведеного аналізу вдалося виявити деякі наявні недоліки правового регулювання таких повноважень в Україні та запропонувати можливі шляхи їх вирішення.

Встановлено, що запровадження в зарубіжних країнах певного організаційно-правового механізму здійснення делегованих державних повноважень органів місцевого самоврядування знаходиться в безпосередній залежності від сприйняття тісї чи іншої концепції місцевого самоврядування.

У більшості європейських країн модель місцевого управління була сформована відповідно до концепції муніципального дуалізму. Здійснення делегованих повноважень грунтується на принципі свободи пристосування до місцевих умов, що надає право муніципальним органам вимагати від держави виділення фінансових ресурсів для розвитку власних управлінських можливостей та відмовлятися від виконання таких повноважень за умови їх недостатнього фінансування.

В Україні, на відміну від європейських держав, які нині підвищують ефективність чинної системи управління та покращують інструменти стимулювання регіонального та місцевого розвитку, ще не завершений інституційний етап формування сучасної соціально орієнтованої системи територіальної організації влади. Ключову роль у такій системі має відігравати саме місцеве самоврядування. Реальне місцеве самоврядування дасть змогу підвищити ефективність муніципальної влади та буде сприяти імплементації європейських стандартів та кращого досвіду зарубіжних держав у сфері делегування повноважень.

\section{АНОТАЦІЯ}

У статті здійснено порівняльний аналіз нормативних моделей власних і делегованих повноважень органів місцевого самоврядування, встановлені їхні спільні та відмінні риси. Розглянуто деякі недоліки правового регулювання делегованих повноважень в Україні та сформульовано пропозиції щодо їх вирішення. Аргументовано, що найбільш оптимальною моделлю правової регламентації інституту делегування повноважень є прийняття окремого, базового закону. 
Проаналізовано досвід окремих європейських держав щодо правового регулювання і здійснення делегованих повноважень залежно від концепцій місцевого самоврядування в країні. Виявлені деякі проблемні питання делегованих повноважень у зарубіжних країнах та шляхи їх подолання. Розроблено пропозиції щодо можливості запозичення кращих заходів організаційно-правового та матеріально-фінансового характеру у сфері делегування державних повноважень європейських країн для України.

\section{ЛІТЕРАТУРА}

1. Батанов О.В. Муніципальна влада в Україні: проблеми теорії та практики : монографія. Київ : Юрид. думка, 2010. 656 с.

2. Європейська хартія місцевого самоврядування: Хартія, міжнародний документ від 15.10.1985 p. URL: http://zakon2.rada.gov.ua/ laws/show/994_036.

3. Конституція України : Конституція, Закон України від 28.06.1996 р. № 254к/96-ВР. Відомості Верховної Ради. 1996. № 30. Ст. 141.

4. Кравченко В.В. Форми участі неурядових структур у розвитку місцевого самоврядування. Актуальні проблеми виконання законів України «Про місиеве самоврядування в Украӥні» та «Про місиеві державні адміністрації» / за ред. В.В. Кравченка. Київ : Атіка, 2003. С. 51-53.

5. Любченко П.М. Місцеве самоврядування в системі інститутів громадського суспільства: конституційно-правовий аспект : автореф. дис. ... д-ра юрид. наук : 12.00.02 / Нац. юрид. акад. України ім. Я. Мудрого. Харків, 2008. 40 с.

6. Любченко П.М. Муніципальне право України : навч. посібник. Харків : ФІНН, 2012. 496 с.

7. Онупрієнко А.М. Делегування державних повноважень місцевим органам влади: світовий досвід. Проблеми законності. 2009. № 102. C. $28-35$.

8. Про внесення змін до деяких законодавчих актів України щодо розширення повноважень органів місцевого самоврядування та оптимізації надання адміністративних послуг: Закон України від 10.12.2015 р. №888-VIII. Відомості Верховної Ради України. 2016. № 3. Ст. 30.

9. Про затвердження Порядку контролю за здійсненням органами місцевого самоврядування делегованих повноважень органів виконавчої влади : Порядок, Постанова Кабінету Міністрів України від 09.03.1999 р. № 339. Офіиійний вісник Украӥни. 1999. № 10. Ст. 390.

10.Про місцеве самоврядування в Україні: Закон України від 21.05.1997 р. № 280/97-ВР. Відомості Верховної Ради Украӥни. 1997. № 24. Ст. 170. 
11. Проблеми функціонування місцевих рад та їх виконавчих органів : монографія / за ред. Ю.М. Тодики. Харків : Право, 2009. 540 с.

12. Васильев В.И. Местное самоуправление : учеб. и науч.-практич. пособие. Москва : Юринформцентр, 1999. 453 с.

13. Пивоваров К. А. Делегирование государственных полномочий местным органам власти: зарубежный опыт. Сибирский Юридический Вестник. 2002. № 1. URL: http://www.lawinstitut.ru/ru/science/vestnik/20021/ pivovarov.html.

14. Assigning competences and functions to local self-government in four EU member states: a comparative review / prepared by Prof. Salvador Parrado. Madrid: SIGMA, 2005. URL: http://www.sigmaweb.org/ publications/40987105.pdf.

15. Local and regional democracy in Spain: reccomendation 336 (2013) CG(24)6FINAL / rapporteurs: Marc Cools, Leen Verbeek. Strasbourg, 19-21 March 2013. URL: https://wcd.coe.int/ViewDoc.jsp?p=\&id=2041471\& Site $=\&$ direct $=$ true.

16. Local authority Competence in Europe. Study of the European Committee on Local and Regional Democracy / Prepared with the colaboration of Gerard Marcou, Prof. at Paris I Pantheon-Sorbonne University, Head of the Grale. European Practice Reports. Council of Europe, 08 september 2007. URL: https://wcd.coe.int/ViewDoc.jsp?p=\&id=2041471\&Site=\& direct=true.

17. Managing across levels of government Spain. OECD Journal on Budgeting. 1997. P. 387-402.

18. Popa V., Munteanu I. Local Government Reforms in the Former Soviet Union: Between Hope and Change. Local governments in Eastern Europe, in the caucasus and in Central Asia. URL: http://unpan1.un.org/intradoc/groups/ public/documents/APCITY/UNPAN008028.pdf.

19. Sauer A. The System of the Local Self-Governments in Poland. Research paper. 2013. № 6.25 p. URL: https://www.amo.cz/wp-content/.../ amocz-RP-2013-6.pdf .

20. Serohina S., Bodrova I., Novak A. Delegation of State Powers to Local Self-Government Bodies: Foreign Experience and Ukrainian Realities. Baltic Journal of European Studies. Tallinn University of Technology, 2019. Vol. 9, No. 3 (28). P. 262-285.

21. À la répartition de compétences entre les communes, les départements, les régions et l'Etat *loi Defferre*: Loi du 7 janvier 1983 relative $n^{\circ}$ 83-8 (version consolidée au 08 septembre 2017). URL: https://www.legifrance. gouv.fr/affichTexte.do?cidTexte=JORFTEXT000000320197.

22. Actes I et II de la décentralisation: évolution des compétences des collectivités territoriales, la situation en 2008. La France: des territoires en 
mutation. 2009. URL: http://geoconfluences.ens-lyon.fr/doc/territ/FranceMut/ FranceMutDoc3.htm.

23. Constitution de la République française: constitution du 4 octobre 1958 (Version mise à jour en janvier 2015). URL: http://www.assembleenationale.fr/connaissance/constitution.asp\#titre_12.

24. Décentralisation et enseignement: dossiers documentaries / Ministère de l'éducation. URL: http://media.education.gouv.fr/file/40/4/1404.pdf.

25. Les grandes étapes de la décentralisation en France / Line Arsenault. Ministère des Affaires municipales et des Régions. le 21 février 2005. URL: http://www.mamrot.gouv.qc.ca/pub/observatoire_municipal/ veille/decentralisation_france.pdf.

26. La Constitución española: Constitución de 29.12.1978. «BOE». 1978. núm. 311, 112 págs. URL: http://www.congreso.es/consti/constitucion/indice/ titulos/articulos.jsp?ini $=143 \&$ fin $=158 \&$ tipo $=2$.

27. Reguladora de las Bases del Régimen Local, Ley 7/1985, de 2 de abril. «BOE». 1985. № 80. 20 págs. URL: http://noticias.juridicas.com/base_datos/ Admin/17-1985.t1.html.

28. Constituição da República Portuguesa: Sétima Revisão Constitucional 2005. Diário da República. n. ${ }^{\circ} 155$ - I Série - A, de 12 de agosto de 2005. URL: https://www.parlamento.pt/ArquivoDocumentacao/Documents/ CRPVIIrevisao.pdf

29. Descentralização de competências: anteprojeto de Decreto-Lei. Dossier Municipalização. 2014. URL: http://www.fenprof.pt/Download/FENPROF/ SM_Doc/Mid_115/Doc_9133/Anexos/Anteprojeto_de_Decreto_Lei_descentralizacao_de_competencias1.pdf.

30. Lei das Finanças Locais: Lei n. ${ }^{\circ}$ 2/2007. Diário da República, 15 de Janeiro de 2007. 1.a série. N.o 10. URL: http://www.cm-cascais.pt/sites/default/ files/anexos/gerais/new/lei_das_financas_locais.pdf.

31. Programa de Reestruturação da Administração Central do Estado: Relatório Final / Comissão Técnica do Prace. Descentralização. 2006. Anexo 4. 187 p. URL: http://repositorio.ul.pt/bitstream/10451/6291/34/ulsd062670_ td_anexo_3_PRACE_5.pdf.

32. Regime jurídico das autarquias locais: Lei de 12 de Setembro n. ${ }^{\circ} 75 / 2013$. URL: http://www.pgdlisboa.pt/leis/lei_mostra_articulado.php?nid=1990\& tabela=leis.

33. Transferência de atribuições e competências para as autarquias locais: lei de 14 de Setembro n. ${ }^{\circ} 159 / 99$. URL: http://www.idesporto.pt/ficheiros/file/ Lei_159_1999.pdf.

34. Konstytucja Rzeczypospolitej Polskiej: z dnia 2 kwietnia 1997 r. Dz.U., 1997. NR 78. poz. 483. URL: http://www.sejm.gov.pl/prawo/konst/polski/ kon1.htm. 
35. O samorządzie gminnym: ustawa z dnia 8 marca 1990 r Dz.U. 1990. Nr 16. poz. 95. URL: http://isap.sejm.gov.pl/DetailsServlet?id=WDU19900160095.

36. O samorządzie powiatowym: ustawa z dnia 5 czerwca 1998 r. Dz.U. 1998. $\mathrm{Nr}$ 91. poz. 578. URL: http://isap.sejm.gov.pl/DetailsServlet?id= WDU19980910578.

37. O samorządzie województwa: ustawa z dnia 5 czerwca 1998 r. Dz.U. 1998. $\mathrm{Nr}$ 91. poz. 576. URL: http://isap.sejm.gov.pl/DetailsServlet?id= WDU19980910576.

\section{Information about author:}

Novak A. O.,

Candidate of Science of Law, Assistant of the Department of State Construction Yaroslav Mudryi National Law University 77, Pushkinska str., Kharkiv, Ukraine

DOI https://doi.org/10.30525/978-9934-588-43-3/2.14 